\title{
Pauline Bruley, Rhétorique et style dans la prose de Charles Péguy
}

\section{Ida Merello}

\section{Q OpenEdition}

1 Journals

\section{Edizione digitale}

URL: http://journals.openedition.org/studifrancesi/5741

DOI: 10.4000/studifrancesi.5741

ISSN: 2421-5856

\section{Editore}

Rosenberg \& Sellier

\section{Edizione cartacea}

Data di pubblicazione: 1 septembre 2011

Paginazione: 450

ISSN: 0039-2944

\section{Notizia bibliografica digitale}

Ida Merello, «Pauline Bruley, Rhétorique et style dans la prose de Charles Péguy», Studi Francesi [Online], 164 (LV | II) | 2011, online dal 30 novembre 2015, consultato il 13 janvier 2021. URL: http:// journals.openedition.org/studifrancesi/5741 ; DOI: https://doi.org/10.4000/studifrancesi.5741

Questo documento è stato generato automaticamente il 13 janvier 2021.

\section{(c) (i) (9)}

Studi Francesi è distribuita con Licenza Creative Commons Attribuzione - Non commerciale - Non opere derivate 4.0 Internazionale. 


\section{Pauline Bruley, Rhétorique et style dans la prose de Charles Péguy}

Ida Merello 


\section{NOTIZIA}

PAULINE BRULEY, Rhétorique et style dans la prose de Charles Péguy, Paris, Champion, 2010, 440 pp.

Bel saggio, in cui l'A. mette a confronto gli studi scolastici della retorica classica e delle lettere greche e romane con la prosa di Péguy, per individuare se, e in che misura, la sua scelta di uno stile "semplice" e vivo rappresenti in realtà un'altra forma di retorica appresa dal confronto con i classici. Nella prima parte dell'opera l'A. indaga in profondità quali fossero gli studi di retorica al momento delle riforme che hanno coinvolto Péguy proprio nel periodo scolastico, esaminando gli esercizi che venivano normalmente proposti e fornendo preziose informazioni tratte da esempi conservati dallo stesso scrittore. Emerge così come il gusto della semplicità nasca per lui dall'incontro tra il modello di chiarezza della tradizione accademica e la vivace ripresa di quel medesimo modello alla fine del XIX secolo come valore di opposizione alla lingua simbolista. L'A. dimostra perciò come semplicità per Péguy non significhi piattezza o neutralità, ma ricerca di un'autenticità nei confronti della realtà, e quindi di uno stile personale molto sorvegliato, alla ricerca del «mot juste», che riveli la tensione etica del suo essere. Attraverso una ricca documentazione viene quindi messo in luce il pensiero di Péguy sia in rapporto agli scrittori del passato che alla filosofia di Bergson. Nella seconda parte del lavoro, l'A. studia sistematicamente la scrittura di Péguy come «subversion et conversion» della retorica, mostrando la sua opposizione non solo alla retorica scolastica ma anche a quella politica, e il modo in cui i dispositivi retorici della tradizione servono per innovare dall'interno lo stile della passione politica. Il volume è accompagnato da una ricca bibliografia. 